\title{
SPECIFICS IN BRAND VALUE SOURCES OF CUSTOMERS IN THE BANKING INDUSTRY FROM THE PSYCHOGRAPHIC POINT OF VIEW
}

Gajanova, L., Nadanyiova, M., Lazaroiu, G.

Lubica Gajanova / University of Zilina, Faculty of Operation and Economics of Transport and Communications, Department of Economics, Univerzitna 1, Zilina, Slovakia. Email: lubica.gajanova@fpedas.uniza.sk.

Margareta Nadanyiova / University of Zilina, Faculty of Operation and Economics of Transport and Communications, Department of Economics, Univerzitna 1, Zilina, Slovakia. Email: margareta.nadanyiova@fpedas.uniza.sk.

George Lazaroiu / Spiru Haret University, Department of Economic Sciences, Strada Ion Ghica 13, Bucharest, Romania. Email: phd_lazaroiu@yahoo.com.

\begin{abstract}
Financial institutions have not paid much attention to customers in the past. In the Slovak republic, this approach has changed only since the late 1990s. Banks have recognized that understanding the customer and its behaviour is key to their success. This contribution aims to answer the research question of whether there are different segments of customers (generations) that would differ in the level of perception of the bank's brand subconsciously. The data used in the presented study was obtained by our survey carried out by a sample size of 2000 respondents (Slovak citizens older than 15 years of age). The given data has been statistically evaluated by testing hypotheses and the factor analysis supported by the implementation of the Kaiser-Meyer-Olkin (KMO) Test, Bartlett's test of sphericity, and calculation of Cronbach's Alpha for brand value sources in general as well as for all generation. In accordance with previously mentioned, the results consist of the identification of specifics in brand value sources in the banking industry on the case study of Slovak Republic creating so a platform for future research of relevant disparities in cross-cultural brand value sources from the psychographic point of view.

Implications for the Central European audience: There are some implications of the article in managerial practice. First of all, the paper presents a valuable source of relevant information for brand managers. They are anticipated to enhance and deepen the understanding of managerial previous practice as well. Overall, the findings help to understand the complexity of internal and external factors motivating consumers to interact with the brand, generating added value for consumers.
\end{abstract}

Keywords: customer behaviour; bank industry; psychographic segmentation JEL Classification: M31, G20 


\section{Introduction}

Financial institutions have not paid much attention to customers in the past. This is related to the slow adoption of marketing philosophy. Only since the late 1990s, this approach has changed in the Slovak Republic (Kliestikova et al, 2017). Matušínská (2009) adds that financial institutions have recognized that understanding the customer and its behavior, including capturing social trends and changes that affect future customer behavior, is key to their success. For the analysis of customers, financial institutions have previously used purely financial analysis. The results of this kind of analysis have only a nominal significance. If we want to carry out a thorough market segmentation, but also to know some of the causes of the results of financial analysis, it is necessary to become familiar with the behavior and attitudes of customers (Carter \& Yeo, 2018; Sroka, 2014). In this context, it is necessary to decide how many segments the financial institution will focus on and which segment is most interesting to it. (Ahmad et al., 2018). Within segments, it is important to find out what associations in their minds link with the brand (Kliestikova \& Janoskova, 2017; Krizanova \& Majerova, 2013). Brands with a high level of consumer awareness and a strong, evolving, unique brand association are coupled with high value (Keller, 2007). Such an opinion is consistent with many other authors. In a more basic concept, favorable associations with the brand arise by convincing the customer that the brand has the appropriate features and benefits to satisfy their needs and wishes (Pakurár et al., 2019) to create an overall positive opinion on the brand.

\section{Literature review}

The existence of a fundamental schism of the principal construct of the brand across markets in their regional perception has already been found in the scientific literature. (Heinberg et al., 2018, Kliestikova et al., 2019) The basis of this theory was to demonstrate the dual perception of the brand - primarily in its status level (brand management in the traditional market economies), respectively, primarily in the context of its qualitative parameters (brand management in former transit economies or emerging markets). (Lizbetinova \& Weberova, 2016). The identification of this phenomenon has prompted the need to revise existing models of the brand building and management, especially with the emphasis on the need to review the position of communication and product policy in the marketing mix. Contemporary market reality indicates that traditional economic theories are failing and there is a need to reassess them by a behavioural approach that includes both, sociological and psychological aspects of the examined economic phenomena. While for some areas of economic theory and practice is such an innovative approach (Mala \& Benickova, 2018), in other areas it is experiencing its renaissance. Such a renaissance also takes place within the brand management that stresses the behavioural approach across all its theoretical concepts. However, these concepts record the occurrence of an increasing number of exceptions from their historically proclaimed universal validity in the confrontation with the present economic process, which creates the need for their revision.

Tatoglu et al. (2018) have developed the theory of brand value sources and diversity among emerging markets highlighting the aspect of cross-product variability. Unfortunately, contemporary research does not take into consideration the penetration of regional and product categories with the intention to modify traditional managerial approaches with respect to specific brand value sources. The brand value sources vary primarily concerning 
the consumer behaviour mechanism that is typical for the reviewed branded product and which at the same time converges the most with the identified national socio-cultural profile (Kliestikova et al., 2017). According to Voyer et al. (2017) until now there is no explanation of the individual socio-cultural characteristics of consumers in the context of the sources of their perceived brand value in the literature. Parameters that are relevant in the context of exploring the sources of the subjectively perceived brand value are identified differently in the literature. Baalbaki \& Guzman (2016) state the need to re-evaluate the traditional brand equity model. According to them the literature lacks an empirically based consumerperceived brand equity scale despite the importance of the concept and the need for brand equity measures. Their article develops a brand equity conceptualization and a scale determined by dimensions that consumers perceive. This consumer-perceived and consumer-based brand equity scale is made up of four dimensions: quality, preference, social influence, and sustainability. However, the applicability of this modified model is after some time disputed by Stocchi \& Fuller (2017). Huang et al. (2016) accentuate the socalled brand relationship quality (BRQ) and customer relationship quality (CRQ). They state on the example of retail services that it is more important to depart from this approach and demonstrate the mediating roles of brand relationship quality (BRQ) and customer relationship quality $(\mathrm{CRQ})$ in the relationship between brand benefits and brand loyalty in retail service contexts, while the literature often pays particular attention to how brand benefits develop relationship quality, such as trust and satisfaction. Dwivedi et al. (2016) emphasize the so-called brand recognition as the underlying parameter of the subjectively perceived value. They conceptualise the theoretical framework of brand management by demonstrating the importance of the consumer brand knowledge, the category involvement, and the corporate-level associations in driving engagement behaviours, thereby accommodating the role of brand-level, category-level, and corporate-level factors. Czubala (2016) states that brand awareness is an essential part of the brand attitudes. Saenger et al. (2017) accentuate in the context of exploring the brand value the element attributes. They provide a case study and state that broadening the brand positioning is challenging because the strong brand images are resistant to change. This is the reason why consumers are likely to reject attempts to associate new discrepant attributes due to the incongruence with the brand's existing image. Yu et al. (2017) state that consumers tend to imagine product features, functions, or usage that they have learned from previous exposure to and experiences with brands, especially when they engage in online apparel shopping. Prior brand-related factors, such as brand familiarity and brand loyalty, may influence imagery elaboration - the activation of stored information in the production of mental images beyond that provided by the stimulus.

Keller (2007) and Porto (2018) according to Aaker's traditional CBBE brand value model describe various types of elements of brand value: attributes (product related and nonproduct related), benefits (functional, experiential and symbolic) and attitudes. Attributes are those descriptive features that characterize a brand, such as what a consumer thinks the brand is or has and what is involved with its purchase or consumption. Benefits are the personal value consumers attach to the brands' attributes, that is, what consumers think the brand can do for them. Brand attitudes are consumers' overall evaluations of a brand (Del Rio et al., 2001; Ergin et al., 2011). The comparison of elements of brand value within the selected national socio-cultural profile across product categories in specific literature is still absent. It is not needed to take account of behavioural specificities of brand management 
not only across markets but also across segments. The identified shortcoming is removed by the study presented by us in the present paper. However, there are still many issues that should be analysed in the scientific literature. The main one is the critical discussion of findings in the scope of generational approach to consumers as this trend in brand management has been set by contemporary scientific literature and its importance has been identified as significant. The identified shortcoming is removed by the study presented by us in the present paper.

\section{Methodology}

Based on the analysis of secondary data from the research topic, it can be assumed choosing what kind of favourable and unique association, i.e. brand value sources link with the brand requires careful consumer analysis. For this reason, we focused on exploring brand associations within the science project APVV „Integrated model of management support for building and managing the brand value in the specific conditions of the Slovak Republic". The research was conducted in a specific banking sector and focused on the psychographic point of view. Psychographic segmentation criteria divide consumers into different segments based on belonging to particular social classes, based on different lifestyles or types of personalities (Kotler \& Armstrong, 2004). Their goal is to explain the differences in a market manner based on the psychological and social predispositions of consumers. It seeks to uncover the reasons why some consumers with the same descriptive characteristics show different buying behaviour.

Lifestyle as one of the characteristics of market behaviour can be tracked and analysed from many different viewpoints, often in combination with other segmentation factors. For the purpose of this research, we used lifestyle generational market segmentation (Michman et al., 2003). Understanding generation values and motivation has become essential because each generation is driven by unique ideas about the lifestyle to which it aspires (Smith \& Clurman, 1997). Each generation represents a different set of unique expectations, experiences, generational history, lifestyles, values, and demographics that influence their buying behaviours (Reicher, 2018). This information empowers you to craft a relevant message that draws a direct connection between individuals and how they relate to your brand. There are many studies that identify and analyse differences in consumer behaviour according to the customer generations. For the purposes of this contribution, respondents are segmented into six classifications by their generational cohort: (Post-War Cohort - born: 1928-1945; The Baby Boomers - born: 1946-1954; Generation Jones - born: 1955-1965; Generation X - born: 1966-1976; Generation Y- born: 1977-1994 and Generation Z - born: 1995-2012).

The aim of this contribution is to answer the research question of whether there are different segments of customers (generations) that would differ in the level of perception of the bank's brand in the subconscious. After confirming this assumption, we identify specifics in brand value sources in general as well as for all generations in the banking industry on the case study of Slovak Republic. For these analyses, the primary data were used through a questionnaire survey conducted within the APVV project using the method CAWI (Computer Assisted Web Interviewing) by an external agency. The implementation of the questionnaire survey took place between January and March 2019 on a socio-demographic representative sample of 2.000 respondents who were Slovaks over 15 years of age. The reason for such a limitation was the requirement to ensure the autonomy of purchasing 
decisions and the real mirroring of the value of the brand in the economic behaviour of the Slovak population. The structure of the surveyed sample was socio-demographically representative.

Referring to the quadratic typology of purchasing behaviour, depending on the degree of engagement and differentiation (Bracinikova \& Matusinska, 2017; Peters, 2017) and the national socio-cultural profile of the Slovak Republic, it is possible to identify as a relevant type of buying behaviour the so-called dissonance-reducing buying behaviour characterized by a high engagement in obtaining additional information about products and little differences between brands. A suitable product for examining the internal variability of subjectively perceived sources of the brand value in the conditions of the specific market of the Slovak Republic are bank brands in the context of the above mentioned. On the other side, secondary data were obtained from the sociocultural profiles of the countries according to Geert Hofstede ${ }^{1}$ From the viewpoint of usability in economic sciences, Hsu et al. (2013) indicated the sociological model of cultural specifics, the so-called Hofstede model of socio-cultural dimensions as the most appropriate. This model was created in the $80 \mathrm{~s}$ of the 20th century. The reliability and validity of this model were verified in the context of current global change by Basnakova et al. (2016). This model defines the socio-cultural profiles of the countries using six basic attributes, namely: 1) power distance; 2) individualism; 3) masculinity; 4) uncertainty avoidance; 5) long term orientation and 6) indulgence. Mazanec et al. (2015) using this model generally shows the impact of the socio-cultural profile of consumers on their purchasing behaviour. The impact of national specifics on perceived brand value is stated using this model by Hur et al. (2015). However, their findings are only of a general nature, and the issue of detecting the impact of individual socio-cultural profile attributes with the value of the brand is not specified in their research. The Slovak Republic acquires values outside the range values of the scale 0-100 (which are an indicator of the ambiguous characteristic dimensions of socio-cultural profiles and, therefore, their usability in the context of marketing practice is low) in dimensions "power distance" (100), "masculinity" (100) a "long term orientation" (77) - above average values and in dimension "indulgence" (28) below average values ${ }^{2}$. In the context of these findings, in the light of the marketing implications of the questionnaire survey (Sobocinska, 2017), we have compiled a questionnaire and filled the brand value sources (attitudes, attributes and benefits) with each relevant component. These are summarized in Tab. 1.

To answer the primary research question, we have used statistical hypothesis testing. Statistical hypothesis testing is one of the most important statistical inference procedures. The role of statistical inference is to decide on the basis of information from the available choices whether to accept or reject certain hypotheses with respect to the basic sample set (Palus et al., 2014). In order to do so, we proceeded in accordance with the methodology of statistical hypothesis testing, which consists of the following steps: Formulation of the null hypothesis $(\mathrm{H} 0)$; Formulation of the alternative hypothesis $(\mathrm{H} 1)$; Determination of the level of significance ( $\alpha$ ); Calculation of test statistics and probability; and Conclusion (Rimarčík, 2007).

${ }_{1}^{1}$ Available 5/12/2018 on https://geert-hofstede.com/.

${ }^{2}$ Available 5/12/2018 on https://geert-hofstede.com/. 
Table 1 | Components of brand associations

\begin{tabular}{|c|c|c|}
\hline $\begin{array}{l}\text { Brand } \\
\text { associations }\end{array}$ & $\begin{array}{l}\text { Components determining the inclination towards brand } \\
\text { associations }\end{array}$ & \\
\hline Attitudes & $\begin{array}{l}\text { Targeted buying branded products } \\
\text { Regular interest in branded products } \\
\text { Attention of branded products because of considering them to be } \\
\text { better } \\
\text { Attention of branded products because of considering them to be } \\
\text { more prestigious }\end{array}$ & $\begin{array}{l}\text { Component1 } \\
\text { Component2 } \\
\text { Component3 } \\
\text { Component4 }\end{array}$ \\
\hline Attributes & $\begin{array}{l}\text { Awaiting modernity from a branded product } \\
\text { Awaiting quality from a branded product } \\
\text { Awaiting creative advertising from a branded product } \\
\text { Awaiting popularity from a branded product } \\
\text { Awaiting attracting attention from a branded product }\end{array}$ & $\begin{array}{l}\text { Component5 } \\
\text { Component6 } \\
\text { Component7 } \\
\text { Component8 } \\
\text { Component9 }\end{array}$ \\
\hline Benefits & $\begin{array}{l}\text { Branded product makes me happier } \\
\text { Branded product increases my social status } \\
\text { Branded product makes it easier for me to make friends } \\
\text { Branded product attracts the attention of others } \\
\text { Branded product belongs to my lifestyle }\end{array}$ & $\begin{array}{l}\text { Component10 } \\
\text { Component11 } \\
\text { Component12 } \\
\text { Component13 } \\
\text { Component14 }\end{array}$ \\
\hline
\end{tabular}

Source: authors

Factor analysis operates on the notion that measurable and observable variables can be reduced to fewer latent variables that share a common variance and are unobservable, which is known as reducing dimensionality. These unobservable factors are not directly measured but are essentially hypothetical constructs that are used to represent variables. For example, scores on an oral presentation and an interview exam could be placed under a factor called 'communication ability'; in this case, the latter can be inferred from the former but is not directly measured itself. EFA is used when a researcher wants to discover the number of factors influencing variables and to analyse which variables 'go together'. A basic hypothesis of EFA is that there are common 'latent' factors to be discovered in the dataset, and the goal is to find the smallest number of common factors that will account for the correlations. Another way to look at factor analysis is to call the dependent variables 'surface attributes' and the underlying structures (factors) 'internal attributes'. Common factors are those that affect more than one of the surface attributes and specific factors are those which only affect a particular variable (Yong \& Pearce, 2013; Kovarnik \& Hamplova, 2018).

\section{Results}

To answer the research question, the hypotheses expressing the existence of a statistical dependence between generations and the perception of the bank's brand in the subconscious was established as follows:

$\mathrm{HO}$ : Between generations and perception of the bank's brand in the subconscious there is no statistically significant dependence. 
$\mathrm{H} 1$ : Between generations and perception of the bank's brand in the subconscious there is statistically significant dependence.

The data necessary for testing the hypothesis were obtained by the questionnaire, namely by the following questions: Which brand of a bank operating in Slovakia do you perceive as the most valuable? What is your age? On the basis of age determination, we have included respondents into individual generations. To calculate the test statistic of the first hypothesis, we used the IBM SPSS Statistic software and is shown in Table 1.

Table 2 | Chi-Square Test Results

\begin{tabular}{l|l|r|r}
\hline \multicolumn{2}{l|}{} & \multicolumn{1}{c}{ Value } & \multicolumn{1}{c}{ Approximate Significance } \\
\hline Nominal by Nominal & Phi & 0.341 & 0.000 \\
& Cramer's V & 0.152 & 0.000 \\
\hline N of Valid Cases & 2002 & \\
\hline
\end{tabular}

Source: authors

A significance level was determined at 0.05 and corresponded to a $95 \%$ confidence interval. Based on the comparison of the significance level with the P-value (Significance), the null hypothesis was rejected, and we can confirm an alternative hypothesis, so there is a statistical dependence between the variables. So, we can answer positively the research question, there are different segments of customers (generations) that would differ in the level of perception of the bank's brand in the subconscious.

As mentioned above, primary data obtained through a questionnaire survey was used to develop factor analysis. The survey included sources of types of brand association (attributes, benefits and attitudes) linked with relevant components. Although about multiple components of types of brand association were asked in the questionnaire survey, 14 selected components entered the factor analysis, since the omitted components did not qualify for inclusion. Customer comparison of subjectively perceived brand value sources in general and in the category of each generation was set based on Likert's scale. As part of the factor analysis, we focused primarily on exploring brand associations within the entire core set, i.e. respondents. We subsequently applied the given principle also in segments of individual generations. The data suitability assessment can be started by analysing the correlation matrix of the input variables. Methods of factor analysis requires mutually correlated input variables. The existence of common causes can only be assumed in such a case. To evaluate the interdependence of input variables, the KMO (Kaiser-Meyer-Olkin) test criterion can be used, which is based on a comparison of simple and partial correlation coefficients.

Table 3 | KMO and Bartlett's Test

\begin{tabular}{l|l|r}
\hline \multicolumn{2}{l|}{ Kaiser-Meyer-Olkin Measure of Sampling Adequacy } & .933 \\
\hline \multirow{3}{*}{ Bartlett's Test of Sphericity } & Approx. Chi-Square & 21627.087 \\
& Df & 91 \\
& Sig. & .000 \\
\hline
\end{tabular}

Source: authors 
The KMO (Kaiser-Meyer-Olkin) test has generally shown that the condition of the sample adequacy is met. In the case of brand association analysis in general, the result was 0.933 . A value above 0.9 is considered as excellent. Also, Bartlett's test identifies the dependency between variables. Using it, the hypothesis that the correlation matrix is unitary and thus its value should be less than 0.05 is tested. If the null hypothesis is not rejected, the input data is not suitable for the use of factor analysis. The percentage of total explained variability in the case of brand association resources was $75.786 \%$ (Table 4).

Table 4 | Total Variance Explained

\begin{tabular}{|c|c|c|c|c|c|c|c|c|c|}
\hline \multirow{2}{*}{ Comp. } & \multicolumn{3}{|c|}{ Initial Eigenvalues } & \multicolumn{3}{|c|}{$\begin{array}{l}\text { Extraction Sums of } \\
\text { Squared Loadings }\end{array}$} & \multicolumn{3}{|c|}{$\begin{array}{c}\text { Rotation Sums of Squared } \\
\text { Loadings }\end{array}$} \\
\hline & Total & $\begin{array}{c}\% \text { of } \\
\text { Variance }\end{array}$ & $\begin{array}{c}\text { Cumulative } \\
\%\end{array}$ & Total & $\begin{array}{c}\% \text { of } \\
\text { Variance }\end{array}$ & $\begin{array}{c}\text { Cumulative } \\
\%\end{array}$ & Total & $\begin{array}{c}\% \text { of } \\
\text { Variance }\end{array}$ & $\begin{array}{c}\text { Cumulative } \\
\%\end{array}$ \\
\hline 1 & 7.52 & 53.731 & 53.731 & 7.52 & 53.731 & 53.731 & 4.54 & 32.416 & 32.416 \\
\hline 2 & 1.81 & 12.89 & 66.621 & 1.81 & 12.89 & 66.621 & 3.19 & 22.81 & 55.225 \\
\hline 3 & 1.28 & 9.165 & 75.786 & 1.28 & 9.165 & 75.786 & 2.88 & 20.561 & 75.786 \\
\hline 4 & 0.66 & 4.705 & 80.492 & & & & & & \\
\hline 5 & 0.39 & 2.817 & 83.308 & & & & & & \\
\hline 6 & 0.34 & 2.453 & 85.761 & & & & & & \\
\hline 7 & 0.33 & 2.33 & 88.091 & & & & & & \\
\hline 8 & 0.32 & 2.275 & 90.366 & & & & & & \\
\hline 9 & 0.27 & 1.915 & 92.281 & & & & & & \\
\hline 10 & 0.25 & 1.797 & 94.078 & & & & & & \\
\hline 11 & 0.23 & 1.649 & 95.727 & & & & & & \\
\hline 12 & 0.22 & 1.581 & 97.308 & & & & & & \\
\hline 13 & 0.19 & 1.373 & 98.681 & & & & & & \\
\hline 14 & 0.19 & 1.319 & 100 & & & & & & \\
\hline
\end{tabular}

Source: authors

We can also conclude that the number of significant factors that indicate a given percentage of explained variability is 3 , based on the rule that the value of eigenvalues $>1$. For the individual components of the brand association resources, we have, based on the factor analysis, verified their grouping within individual brand association resources. This was done by calculating a rotated matrix of factor saturations that express the dependence between the component and the factor. High values for factor saturation indicate that the factor significantly affects the indicator. Based on Table 5, we can see that the individual components are grouped into appropriate factors, as they were initially assigned within the implemented questionnaire. 


\begin{tabular}{l|r|r|r}
\hline & $\mathbf{1}$ & $\mathbf{2}$ & $\mathbf{3}$ \\
\hline Component1 & & .840 & \\
Component2 & & .812 & \\
Component3 & & .789 & .870 \\
Component4 & & .797 & .869 \\
Component5 & & & .339 \\
Component6 & & & .805 \\
Component7 & .687 & & .500 \\
Component8 & & & \\
Component9 & & & \\
Component10 & .484 & & \\
Component11 & .707 & & \\
Component12 & .868 & & \\
Component13 & .878 & & \\
Component14 & .867 & & \\
\hline
\end{tabular}

Source: authors

Based on the rotated factor saturation matrix, it is also possible to create the order of brand association resources in general. This order is as follows: 1. Benefits, 2. Attitudes, 3 . Attributes. The inclusion of components 7 and 9 (Awaiting creative advertising from a branded product and Awaiting attracting attention from a branded product) has proven to be a variant. As part of the survey of resources of brand association in general the component Awaiting creative advertising from a branded product shows the importance of first level (first order). Similarly, we analysed the analysis of brand associations between generations. We tested first KMO and Bartlett's Test foreach generation, see Table 6 to 10 .

Table 6 | KMO and Bartlett's Test in Generation Z

\begin{tabular}{l|l|r}
\hline Kaiser-Meyer-Olkin Measure of Sampling Adequacy & .925 \\
\hline \multirow{3}{*}{ Bartlett's Test of Sphericity } & Approx. Chi-Square & 3476.291 \\
& Df & 91 \\
& Sig. & .000 \\
\hline
\end{tabular}

Source: authors

Table 7 | KMO and Bartlett's Test in Generation Y

\begin{tabular}{|c|c|c|}
\hline \multicolumn{2}{|c|}{ Kaiser-Meyer-Olkin Measure of Sampling Adequacy } & .935 \\
\hline \multirow{3}{*}{ Bartlett's Test of Sphericity } & Approx. Chi-Square & 8649.477 \\
\hline & df & 91 \\
\hline & Sig. & .000 \\
\hline
\end{tabular}

Source: authors 
Table 8 | KMO and Bartlett's Test in Generation X

\begin{tabular}{l|l|r}
\hline \multicolumn{2}{l|}{ Kaiser-Meyer-Olkin Measure of Sampling Adequacy } & .917 \\
\hline \multirow{3}{*}{ Bartlett's Test of Sphericity } & Approx. Chi-Square & 4838.472 \\
& df & 91 \\
& Sig. & .000 \\
\hline
\end{tabular}

Source: authors

Table 9 | KMO and Bartlett's Test in Generation Jones.

\begin{tabular}{|c|c|c|}
\hline \multicolumn{2}{|c|}{ Kaiser-Meyer-Olkin Measure of Sampling Adequacy } & \multirow{2}{*}{$\begin{array}{r}.918 \\
4227.227\end{array}$} \\
\hline \multirow{3}{*}{ Bartlett's Test of Sphericity } & Approx. Chi-Square & \\
\hline & df & 91 \\
\hline & Sig. & .000 \\
\hline
\end{tabular}

Source: authors

Table 10 | KMO and Bartlett's Test in Baby boomers.

\begin{tabular}{l|r|r}
\hline Kaiser-Meyer-Olkin Measure of Sampling Adequacy & .963 \\
\hline \multirow{3}{*}{ Bartlett's Test of Sphericity } & Approx. Chi-Square & 10985.880 \\
& df & 91 \\
& Sig. & .000 \\
\hline
\end{tabular}

Source: authors

The KMO test has generally shown that the condition of sample adequacy is met in all generations except the Post War Cohort generation. The level of KMO in all adequacy samples is above 0,9 , so the samples can be described as excellent. Also, Bartlett's test in these adequacy samples identifies the dependency between variables. The matrix of the condition of sample adequacy of Post War Cohort generation is not positively defined. Thus, the next steps of this generation's analysis are not adequate.

The percentage of total explained variability in the case of brand association resources in generation $Z$ is $72,265 \%$ (Table 11), in generation $Y$ it is $78,691 \%$ (Table 13), in generation $X 75,451 \%$ (Table 15), and in Generation Jones, it is $77,409 \%$ (Table 17). The highest percentage of total explained variability is by the generation Baby Boomers $(88,382 \%)$, but this is the variability of only one significant factor, so there is no reason to set up the rotated factor saturation matrix. In other cases (generations) the number of significant factors indicates that a given percentage of explained variability is 3 , based on the rule that the value of eigenvalues $>1$. 
Table 11 | Total Variance Explained in Generation Z

\begin{tabular}{|c|c|c|c|c|c|c|c|c|c|}
\hline \multirow{2}{*}{ Comp. } & \multicolumn{3}{|c|}{ Initial Eigenvalues } & \multicolumn{3}{|c|}{$\begin{array}{l}\text { Extraction Sums of } \\
\text { Squared Loadings }\end{array}$} & \multicolumn{3}{|c|}{$\begin{array}{c}\text { Rotation Sums of Squared } \\
\text { Loadings }\end{array}$} \\
\hline & Total & $\begin{array}{c}\% \text { of } \\
\text { Variance }\end{array}$ & $\begin{array}{c}\text { Cumulative } \\
\%\end{array}$ & Total & $\begin{array}{c}\% \text { of } \\
\text { Variance }\end{array}$ & $\begin{array}{l}\text { Cumulati } \\
\text { ve } \%\end{array}$ & Total & \begin{tabular}{c|}
$\%$ of \\
Variance
\end{tabular} & $\begin{array}{l}\text { Cumulati } \\
\text { ve } \%\end{array}$ \\
\hline 1 & 7.05 & 50.355 & 50.355 & 7.05 & 50.355 & 50.355 & 4.32 & 30.888 & 30.888 \\
\hline 2 & 1.94 & 13.912 & 64.267 & 1.94 & 13.912 & 64.267 & 2.92 & 20.917 & 51.805 \\
\hline 3 & 1.12 & 7.998 & 72.265 & 1.12 & 7.998 & 72.265 & 2.86 & 20.460 & 72.265 \\
\hline 4 & 0.67 & 4.819 & 77.084 & & & & & & \\
\hline 5 & 0.46 & 3.317 & 80.401 & & & & & & \\
\hline 6 & 0.43 & 3.071 & 83.472 & & & & & & \\
\hline 7 & 0.40 & 2.911 & 86.383 & & & & & & \\
\hline 8 & 0.36 & 2.628 & 89.011 & & & & & & \\
\hline 9 & 0.31 & 2.273 & 91.284 & & & & & & \\
\hline 10 & 0.30 & 2.201 & 93.485 & & & & & & \\
\hline 11 & 0.28 & 2.040 & 95.525 & & & & & & \\
\hline 12 & 0.25 & 1.831 & 97.357 & & & & & & \\
\hline 13 & 0.19 & 1.415 & 98.771 & & & & & & \\
\hline 14 & 0.17 & 1.229 & 100.000 & & & & & & \\
\hline
\end{tabular}

Source: authors

Table 12 | Rotated Component Matrix in Generation Z

\begin{tabular}{l|l|l|l}
\hline & $\mathbf{1}$ & $\mathbf{2}$ & $\mathbf{3}$ \\
\hline Component1 & & & 0.832 \\
${ }^{*}$ Component2 & & & 0.802 \\
Component3 & & $\mathbf{0 . 4 3 4}$ & 0.626 \\
Component4 & & & 0.788 \\
Component5 & & 0.836 & \\
Component6 & & 0.817 & \\
Component7 & $\mathbf{0 . 6 4 1}$ & 0.317 & \\
Component8 & & 0.770 & \\
Component9 & $\mathbf{0 . 4 1 9}$ & 0.545 & \\
Component10 & 0.694 & $\mathbf{0 . 4 0 1}$ & \\
Component11 & 0.875 & & \\
Component12 & 0.877 & & \\
Component13 & 0.868 & & \\
Component14 & 0.814 & & \\
\hline Source: auth0rs & & & \\
\hline
\end{tabular}

Source: authors 
Table 13 | Total Variance Explained in Generation Y

\begin{tabular}{|c|c|c|c|c|c|c|c|c|c|}
\hline \multirow{2}{*}{ Comp. } & \multicolumn{3}{|c|}{ Initial Eigenvalues } & \multicolumn{3}{|c|}{$\begin{array}{l}\text { Extraction Sums of } \\
\text { Squared Loadings }\end{array}$} & \multicolumn{3}{|c|}{\begin{tabular}{|c|}
$\begin{array}{c}\text { Rotation Sums of Squared } \\
\text { Loadings }\end{array}$ \\
\end{tabular}} \\
\hline & Total & $\begin{array}{c}\% \text { of } \\
\text { Variance }\end{array}$ & $\begin{array}{c}\text { Cumulative } \\
\%\end{array}$ & Total & $\begin{array}{c}\% \text { of } \\
\text { Variance }\end{array}$ & $\begin{array}{c}\text { Cumulative } \\
\%\end{array}$ & Total & $\begin{array}{c}\% \text { of } \\
\text { Variance }\end{array}$ & $\begin{array}{c}\text { Cumulative } \\
\%\end{array}$ \\
\hline 1 & 8.062 & 57.586 & 57.586 & 8.062 & 57.586 & 57.586 & 4.776 & 34.112 & 34.112 \\
\hline 2 & 1.763 & 12.591 & 70.177 & 1.763 & 12.591 & 70.177 & 3.308 & 23.628 & 57.74 \\
\hline 3 & 1.192 & 8.514 & 78.691 & 1.192 & 8.514 & 78.691 & 2.933 & 20.952 & 78.691 \\
\hline 4 & 0.584 & 4.172 & 82.863 & & & & & & \\
\hline 5 & 0.38 & 2.715 & 85.578 & & & & & & \\
\hline 6 & 0.316 & 2.259 & 87.837 & & & & & & \\
\hline 7 & 0.266 & 1.897 & 89.735 & & & & & & \\
\hline 8 & 0.264 & 1.886 & 91.62 & & & & & & \\
\hline 9 & 0.241 & 1.721 & 93.341 & & & & & & \\
\hline 10 & 0.222 & 1.587 & 94.929 & & & & & & \\
\hline 11 & 0.202 & 1.446 & 96.374 & & & & & & \\
\hline 12 & 0.179 & 1.281 & 97.655 & & & & & & \\
\hline 13 & 0.177 & 1.264 & 98.919 & & & & & & \\
\hline 14 & 0.151 & 1.081 & 100 & & & & & & \\
\hline
\end{tabular}

Source: authors

Table 14 | Rotated Component Matrix in Generation Y

\begin{tabular}{l|l|l|l}
\hline & 1 & \multicolumn{1}{|c|}{$\mathbf{2}$} & \multicolumn{1}{l}{3} \\
\hline Component1 & & .839 & \\
Component2 & & .812 & \\
Component3 & & .799 & \\
Component4 & & .796 & \\
Component5 & & & .882 \\
Component6 & & & .882 \\
Component7 & .763 & & .304 \\
Component8 & & & .803 \\
Component9 & .551 & & .474 \\
Component10 & .698 & & \\
Component11 & .862 & & \\
Component12 & .874 & & \\
Component13 & .863 & & \\
Component14 & .783 & & \\
\hline
\end{tabular}

Source: authors 
Table 15 | Total Variance Explained in Generation X

\begin{tabular}{|c|c|c|c|c|c|c|c|c|c|}
\hline \multirow{2}{*}{ Comp. } & \multicolumn{3}{|c|}{ Initial Eigenvalues } & \multicolumn{3}{|c|}{$\begin{array}{l}\text { Extraction Sums of } \\
\text { Squared Loadings }\end{array}$} & \multicolumn{3}{|c|}{$\begin{array}{l}\text { Rotation Sums of Squared } \\
\text { Loadings }\end{array}$} \\
\hline & Total & $\begin{array}{c}\% \text { of } \\
\text { Variance }\end{array}$ & $\underset{\%}{\text { Cumulative }}$ & Total & $\begin{array}{c}\% \text { of } \\
\text { Variance }\end{array}$ & $\underset{\%}{\text { Cumulative }}$ & Total & $\begin{array}{c}\% \text { of } \\
\text { Variance }\end{array}$ & $\underset{\%}{\text { Cumulative }}$ \\
\hline 1 & 7.422 & 53018 & 53.018 & 7.422 & 53.018 & 53.018 & 4.404 & 31.459 & 31.459 \\
\hline 2 & 1.814 & 12.96 & 65.977 & 1.814 & 12.96 & 65.977 & 3.362 & 24.012 & 55.471 \\
\hline 3 & 1.326 & 9.473 & 75.451 & 1.326 & 9.473 & 75.451 & 2.797 & 19.98 & 75.451 \\
\hline 4 & 0.807 & 5.767 & 81.218 & & & & & & \\
\hline 5 & 0.396 & 2.827 & 84.045 & & & & & & \\
\hline 6 & 0.372 & 2.66 & 86.704 & & & & & & \\
\hline 7 & 0.334 & 2.387 & 89.091 & & & & & & \\
\hline 8 & 0.296 & 2.115 & 91.206 & & & & & & \\
\hline 9 & 0.263 & 1.881 & 93.087 & & & & & & \\
\hline 10 & 0.227 & 1.625 & 94.712 & & & & & & \\
\hline 11 & 0.203 & 1.453 & 96.165 & & & & & & \\
\hline 12 & 0.193 & 1.376 & 97.542 & & & & & & \\
\hline 13 & 0.181 & 1.295 & 98.836 & & & & & & \\
\hline 14 & 0.163 & 1.164 & 100 & & & & & & \\
\hline
\end{tabular}

Source: authors

Table 16 | Rotated Component Matrix in Generation X

\begin{tabular}{l|r|r|r}
\hline & \multicolumn{1}{|c|}{$\mathbf{1}$} & $\mathbf{2}$ & $\mathbf{3}$ \\
\hline Component1 & & .857 & \\
Component2 & & .823 & \\
Component3 & & .818 & \\
Component4 & & .783 & \\
Component5 & & & .871 \\
Component6 & & & .900 \\
Component7 & .590 & .438 & .337 \\
Component8 & & & .756 \\
Component9 & .425 & & .451 \\
Component10 & .753 & & \\
Component11 & .870 & & \\
Component12 & .875 & & \\
Component13 & .872 & & \\
Component14 & .773 & & \\
\hline
\end{tabular}

Source: authors 
Table 17 | Total Variance Explained in Generation Jones

\begin{tabular}{|c|c|c|c|c|c|c|c|c|c|}
\hline \multirow{2}{*}{ Comp. } & \multicolumn{3}{|c|}{ Initial Eigenvalues } & \multicolumn{3}{|c|}{$\begin{array}{l}\text { Extraction Sums of } \\
\text { Squared Loadings }\end{array}$} & \multicolumn{3}{|c|}{$\begin{array}{c}\text { Rotation Sums of Squared } \\
\text { Loadings }\end{array}$} \\
\hline & Total & $\begin{array}{c}\% \text { of } \\
\text { Variance }\end{array}$ & $\begin{array}{c}\text { Cumulative } \\
\%\end{array}$ & Total & $\begin{array}{c}\% \text { of } \\
\text { Variance }\end{array}$ & $\begin{array}{c}\text { Cumulative } \\
\%\end{array}$ & Total & $\begin{array}{c}\% \text { of } \\
\text { Variance }\end{array}$ & $\underset{\%}{\text { Cumulative }}$ \\
\hline 1 & 7.588 & 54.2 & 54.2 & 7.588 & 54.2 & 54.2 & 4.363 & 31.167 & 31.167 \\
\hline 2 & 1.976 & 14.117 & 68.317 & 1.976 & 14.117 & 68.317 & 3.425 & 24.462 & 55.629 \\
\hline 3 & 1.273 & 9.091 & 77.409 & 1.273 & 9.091 & 77.409 & 3.049 & 21.78 & 77.409 \\
\hline 4 & 0.614 & 4.385 & 81.794 & & & & & & \\
\hline 5 & 0.406 & 2.897 & 84.691 & & & & & & \\
\hline 6 & 0.383 & 2.737 & 87.428 & & & & & & \\
\hline 7 & 0.321 & 2.296 & 89.724 & & & & & & \\
\hline 8 & 0.263 & 1.877 & 91.602 & & & & & & \\
\hline 9 & 0.26 & 1.858 & 93.459 & & & & & & \\
\hline 10 & 0.226 & 1.612 & 95.072 & & & & & & \\
\hline 11 & 0.204 & 1.454 & 96.526 & & & & & & \\
\hline 12 & 0.194 & 1.387 & 97.913 & & & & & & \\
\hline 13 & 0.158 & 1.132 & 99.045 & & & & & & \\
\hline 14 & 0.134 & 0.955 & 100 & & & & & & \\
\hline
\end{tabular}

Source: authors

Table 18 | Rotated Component Matrix in Generation Jones

\begin{tabular}{l|l|l|l}
\hline & $\mathbf{1}$ & $\mathbf{2}$ & $\mathbf{3}$ \\
\hline Component1 & & .822 & \\
Component2 & & .813 & \\
Component3 & & .827 & \\
Component4 & & .803 & \\
Component5 & & & .894 \\
Component6 & & & .879 \\
Component7 & .660 & & .408 \\
Component8 & & & .882 \\
Component9 & .547 & & .534 \\
Component10 & .657 & .458 & \\
Component11 & .838 & & \\
Component12 & .869 & & \\
Component13 & .853 & & \\
Component14 & .751 & & \\
\hline
\end{tabular}

Source: authors 


\section{Discussion and Conclusion}

It is important for companies to have a clear understanding of consumer brand associations to develop marketing activities that will in end improve their brand equity. The need to provide revision of traditional strategic concepts with emphasis on behavioural approach has been the leading motive to provide analysis of consumer's perception of brand value sources. Based on the above mentioned, we can conclude that the clustering of brand value components into three main factors (Attitudes, Attributes, and Benefits) has been proved but realised analysis as well as the variation of brand value sources ranking. In all cases, benefits are the most relevant brand value source. In the case of bank brands, it is necessary to build the brand value mainly on this factor. The relevancy of other factors varies. The attitudes are secondary within brand association resources in general as well as in each generation except only one. We have found that in Generation $Z$ the order of importance of brand sources is different and according to another survey, in addition, we can confirm the specialness of the Slovak Generation Z considering national socio-cultural profiles (Brujó, 2018; Francis \& Hoefel, 2018; Cheung et al., 2017a, Cheung et al., 2017b). Therefore, if the brand management applied the basic theoretical model of building and managing its value especially within Generation $Z$ without considering the specificities of the Slovak national socio-cultural profile, it would have a high negative influence on the perceived brand value. The implications of these findings in managerial practice are wide. First, they present a valuable source of relevant information for brand managers and they are anticipated to enhance the understanding of previous practice as well. So, they must strive to understand and provide relevant content to consumers, responding to rapidly changing consumer demands and expectations. Overall, these findings help to understand the complexity of internal and external factors motivating consumers to interact with a brand, generating added value for their consumers. This is useful in marketing practices. The results of this contribution can be used by banks operating in the Slovak Republic, which represents some limits to this survey. But the methodological approach applied in this study can be easily transferred to other research domains. An interesting topic for future research would be an in-depth analysis of brand associations in relation to the calculation of the mean values of the individual components of the brand associations to identify the most important component for each generation or in general for Slovak consumers.

\section{Acknowledgement}

This contribution is an output of scientific project VEGA no. 1/0718/18: The impact of psychographic aspects of pricing on the marketing strategy of companies across products and markets.

\section{References}

Ahmad, I., Oláh, J., Popp, J., \& Máté, D. (2018). Does Business Group Affiliation Matter for Superior Performance? Evidence from Pakistan. Sustainability, 10(9), 3060. https://doi.org/10.3390/su10093060.

Ergin, E. A., Özdemir, H., \& Ozsacmaci, B. (2011). The Effect Of Brand Associations: A Field Study On Turkish Consumers. International Business \& Economics Research Journal (IBER), 5(8), 6574. https://doi.org/10.19030/iber.v5i8.3499.

Baalbaki, S., \& Guzman, F. (2016). A consumer-perceived consumer-based brand equity scale. Journal of Brand Management, 23(2), 229-251. https://doi.org/10.1057/bm.2016.11. 
Basnakova, J., Brezina, I., \& Masaryk, R. (2016). Dimensions of culture: The case of Slovakia as an outlier in Hofstede's research. Ceskoslovenska Psychologie, 60(1), 13-25.

Bracinikova, V., \& Matusinska, K. (2017). Marketing mix of financial services from the customers'perspective. Forum Scientiae Oeconomia, 5(4), 35-48. https://doi.org/10.23762/FSO_VOL5NO4_17_3.

Brujó, G. Brands through the eyes of Generation Z. Retrieved November 15, 2019, from https://www.interbrand.com/views/brands-through-generation-z/.

Carter, S., \& Yeo, C-M. A. (2018). Internet-enabled Collective Intelligence as a Precursor and Predictor of Consumer Behaviour. Economics, Management, and Financial Markets, 13(4), 11-38. https://doi.org/10.22381/EMFM13420181.

Cheung, J., Davis, T., \& Heukaeuferavis, E. (2017). Gen Z brand relationships. Authenticity matters. Retrieved November 15, 2019, from https://cdn.nrf.com/sites/default/files/201810/NRF_GenZ\%20Brand\%20Relationships\%20Exec\%20Report.pdf.

Cheung, J., Glass, S., McCarty, D., \& Wong, C. K. Uniquely Generation Z. What brands should know about today's youngest consumers. Retrieved November 15, 2019, from https://www.generationy20.com/retail-generation-z.PDF.

Czubala, A. (2016). Corporate social responsibility in marketing. Forum Scientiae Oeconomia, 4(1), 103-111.

Del Rio, A. B., Vázquez, R., \& Iglesias, V. (2001). The effects of brand associations on consumer response. Journal of Consumer Marketing, 18(5), 410-425. https://doi.org/10.1108/07363760110398808.

Dwivedi, A., Wilkie, D, Johnson, L., \& Weerawardena, J. (2016). Establishing measures and drivers of consumer brand engagement behaviours. Journal of Brand Management, 23(5), 41-69. https://doi.org/10.1057/s41262-016-0001-9.

Francis, T., \& Hoefel, F. (2018). 'True Gen': Generation Z and its implications for companies. Retrieved November 15, 2019, from https://www.mckinsey.com/ /media/McKinsey/Industries/Consumer\%20Packaged\%20Goods/ Our\%20Insights/True\%20Gen\%20Generation\%20Z\%20and\%20its\%20implications\%20for\%20 companies/Generation-Z-and-its-implication-for-companies.ashx.

Heinberg, M., Ozkaya, H. E., \& Taube, M. (2018). Do corporate image and reputation drive brand equity in India and China? Similarities and differences. Journal of Business Research, 86, 259268. https://doi.org/10.1016/j.jbusres.2017.09.018.

Hsu, S. Y., Woodside, A. G., \& Marshall, R. (2013). Critical tests of multiple theories of cultures' consequences: Comparing the usefulness of models by hofstede, inglehart and baker, schwartz, steenkamp, as well as GDP and distance for explaining overseas tourism behavior. Journal of Travel Research, 52(6), 679-704. https://doi.org/10.1177/0047287512475218.

Huang, S. M., Fang, S. R., Fang, S. C., \& Huang, C. C. (2016). The influences of brand benefits on brand loyalty: Intermediate mechanisms. Australian Journal of Management, 41(1), 141-160. https://doi.org/10.1177/0312896214553516.

Keller, K. L. (2007). Strategické řízení značky. Praha: Grada.

Kliestikova, J., Durana, P., \& Kovacova, M. (2019). Naked Consumer's Mind Under Branded Dress: Case Study of Slovak Republic. Central European Business Review, 8(1), 15-32. https://doi.org/10.18267/j.cebr.208. 
Kliestikova, J., \& Janoskova, K. (2017). Branding with understanding: how national profile of consumer influences brand value perception. Marketing and management of innovations, 3, 149-157. https://doi.org/10.21272/mmi.2017.3-14.

Kliestikova, J., Krizanova A., Corejova, T., Kral, P., \& Spuchlakova, E. (2018). Subsidies to Increase Remote Pollution? Science and Engineering ethics, 24(2), 755-767. https://doi.org/10.1007/s11948-017-9908-0

Kliestikova J., Misankova, M., \& Kliestik, T. (2017). Bankruptcy in Slovakia: international comparison of the creditor's position. Oeconomia Copernicana, 8(2), 221-237. https://doi.org/10.24136/oc.v8i2.14.

Kotler, P., \& Armstrong, G. (2004). Marketing. Praha: Grada.

Kovarnik, J., \& Hamplova, E. (2018). Comparative analysis of foreign trade in selected European $\begin{array}{llll}\text { countries. } & \text { Ekonomicko-manazerske } \quad \text { spektrum, } & 12(2), & 106-117 .\end{array}$ https://doi.org/10.26552/ems.2018.2.106-117.

Krizanova, A., \& Majerova, J. (2013). The proposal of activities of pricing policy in the process of building and managing brand value in Slovak Republic. In Proceedings of the 2013 International Conference on Information, Business and Education Technology (ICIBIET 2013). Beijing: Atlantis Press.

Lizbetinova, L. \& Weberova, D. (2016). Managing attitudes of consumers towards brands and quality. In K. S. Soliman (Eds.) Proceedings of 27th International Business Information Management Association Conference (pp. 2147-+). Milan: INT BUSINESS INFORMATION MANAGEMENT ASSOC-IBIMA.

Mala, D., \& Bencikova, D. (2018). Innovations of a green product. Ekonomicko-manazerske spektrum, 12(1), 64-74. https://doi.org/10.26552/ems.2018.1.64-74.

Matušínská, K. (2009). Marketing finančních služeb: distanční studijní podpora. Karviná: Slezská univerzita v Opavě.

Micman, R. D., Mazze, E. M., \& Greco, A. J. (2003). Lifestyle Marketing: Reaching the New American Consumer. Westport: Praeger.

Pakurár, M., Haddad, H., Nagy, J., Popp, J., \& Oláh, J. (2019). The Service Quality Dimensions that Affect Customer Satisfaction in the Jordanian Banking Sector. Sustainabilty, 11(4), 1113. https://doi.org/10.3390/su11041113.

Palus, M., Matova, H., Krizanova, A., \& Parobek, J. (2014). A survey of awareness of forest certification schemes labels on wood and paper products. Acta Facultatis Xylologiae Zvolen, 56(1), 129138.

Peters, M. A. (2017). Ecopolitical philosophy, education and grassroots democracy: The 'Return' of Murray Bookchin (and John Dewey?). Geopolitics, History, and International Relations, 9(2), 714. https://doi.org/10.22381/GHIR9220171.

Porto, R. B. (2018). Consumer-based brand equity of products and services: Assessing a measurement model with competing brands. Revista Brasileira de Marketing, 17(2), 150-165. https://doi.org/10.5585/remark.v17i2.3547.

Reicher, R. Z. (2018). Hungarian millennials' attitudes on being online. Forum Scientiae Oeconomia, 6(1): 5-18. https://doi.org/10.23762/FSO.

Rimarčík, M., (2007). Štatistika pre prax. Marián Rimarčík. 
Saenger, C., Jewell, R. D., \& Grigsby, J. L. (2017). The strategic use of contextual and competitive interference to influence brand-attribute associations. Journal of Advertising, 46(3), 424-439. https://doi.org/10.1080/00913367.2017.1281776.

Smith, J. W., \& Clurman, A. S. (1997). Rocking the Ages. HarperCollins e-books.

Sobocinska, M. (2017). Marketing research in film and television production management. Forum Scientiae Oeconomia, 5(SI1), 71-78. https://doi.org/10.23762/FSO_vol5sp1_17_7.

Sroka, W., Cygler, J., Gajdzik, B. (2014). The Transfer of Knowledge in Intra-Organizational Networks: A Case Study Analysis. Organizacija, 47(1): 24-34. https://doi.org/10.2478/orga-2014-0003.

Stocchi, L., \& Fuller, R. (2017). A comparison of brand equity strength across consumer segments and markets. Journal of Product and Brand Management, 26(5), 453- 468. https://doi.org/10.1108/JPBM-06-2016-1220.

Tatoglu, E., Sahadev, S., \& Demirbag, M. (2018). Brand management practices in emerging country firms - exploring the patterns of variation and its impact on firm performance. Journal for East European Management Studies, 23(3), 447-473. https://doi.org/10.5771/0949-6181-2018-3447.

Voyer, B. G., Kastanakis, M. N., \& Rhode, A. K. (2017). Co-creating stakeholder and brand identities: A cross-cultural consumer perspective. Journal of Business Research, 70, 399-410. https://doi.org/10.1016/j.jbusres.2016.07.010.

Yong, A. G., \& Pearce, S. (2013). A Beginner's Guide to Factor Analysis: Focusing on Exploratory Factor Analysis. Tutorials in Quantitative Methods for Psychology, 9(2), 79-94. https://doi.org/10.20982/tqmp.09.2.p079.

Yu, U. J., Cho, E., \& Johnson, K. K. P. (2017). Effects of brand familiarity and brand loyalty on imagery elaboration in online apparel shopping. Journal of Global Fashion Marketing, 8(3), 193-206. https://doi.org/10.1080/20932685.2017.1284603.

The research paper passed the review process. | Received: July 9, 2019; Revised: November 30, 2019; Accepted: January 1, 2020; Published: June 15, 2020. 